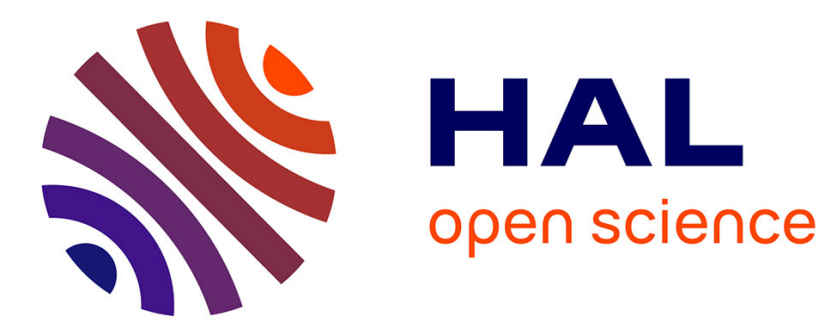

\title{
Moderate oxygen depletion as a factor favouring the filamentous growth of Sphaerotilus natans
}

Marina Seder-Colomina, A. Goubet, S. Lacroix, G. Morin, G. Ona-Nguema, G. Esposito, Eric D. van Hullebusch, J.J. Pernelle

\section{- To cite this version:}

Marina Seder-Colomina, A. Goubet, S. Lacroix, G. Morin, G. Ona-Nguema, et al.. Moderate oxygen depletion as a factor favouring the filamentous growth of Sphaerotilus natans. Antonie van Leeuwenhoek, 2015, 107 (5), pp.1135-1144. hal-01274713

\section{HAL Id: hal-01274713 \\ https://hal.science/hal-01274713}

Submitted on 16 Feb 2016

HAL is a multi-disciplinary open access archive for the deposit and dissemination of scientific research documents, whether they are published or not. The documents may come from teaching and research institutions in France or abroad, or from public or private research centers.
L'archive ouverte pluridisciplinaire HAL, est destinée au dépôt et à la diffusion de documents scientifiques de niveau recherche, publiés ou non, émanant des établissements d'enseignement et de recherche français ou étrangers, des laboratoires publics ou privés. 


\section{Sphaerotilus natans}

\# Correspondence: Marina Seder-Colomina, marina.sedercolomina@u-pem.fr. Université Paris-Est, Laboratoire Géomatériaux et Environnement (LGE), Institut Francilien des Sciences Appliquées, Bât. IFI, 5 Boulevard Descartes - Champs sur Marne, 77454 Marne-la-Vallée, Cedex 2, France. Phone: 0033 (0)1 4932 90 42. Fax: 0033 (0)1 49329137.

* Present address: Veolia Environnement Recherche and Innovation - Pôle Biotechnologies et Agronomie, Centre de Recherche Veolia Environnement de Maisons Laffitte, Maisons - Laffitte, France.
Mis en forme : Français (France)

Mis en forme : Français (France) Mis en forme : Français (France) 
Abstract

Sphaerotilus natans is a neutrophilic iron-related sheath-forming filamentous microorganism that presents dual morphotype: single cells and ensheathed cells forming filaments. As S. natans has been proposed as a sorbent for inorganic pollutants and it is occasionally involved in bulking episodes, elucidating factors affecting its filamentous growth is of crucial interest. The purpose of this work was to evaluate the effect of dissolved oxygen (DO) as a factor affecting $S$. natans filamentation from single cells. A method to quantify $S$. natans under its filamentous and single-cell morphotypes, based on a differential filtration procedure coupled with quantitative real-time PCR, was developed here. Scanning Electron Microscopy was used to validate the filtration step. Under actively aerated conditions (DO maintained at $7.6 \pm 0.1 \mathrm{mg} \mathrm{l}^{-1}$ ), S. natans grew mainly as single cells throughout the experiment, while a depletion in DO concentration (to $\sim 3 \mathrm{mg} \mathrm{l}^{-1}$ ) induced its filamentous growth. Indeed, when oxygen was shortened the proportion of single cells diminished from $83.3 \pm 5.9 \%$ to $14.3 \pm 3.4 \%$ while the filaments increased from $16.7 \pm 5.9 \%$ to $85.7 \pm 3.4 \%$. Our results suggest that oxygen plays a key role in S. natans filamentation and contribute to better understand the factors favouring filamentous growth.

\section{Keywords}




\section{Introduction}

Activated sludge process is a widespread biological technology in wastewater treatment plants (WWTP) and it is known that its efficiency depends on the settling ability of the biomass in the clarifier (Silverstein et al. 1990; Patziger et al. 2012). In such process, the invasive proliferation of filamentous bacteria can drastically reduce the settling ability and produce bulking issues (Jenkins 1992; Martins et al. 2004). Despite their negative implications in WWTP, some filamentous bacteria can also potentially be used as biosorbents (e.g. Cd, Zn, Cu, Ag, Cr(III), Cr(VI), Pb, etc.) (Lodi et al., 1998; Pagnanelli et al., 2003). Hence, identifying factors that affect filamentation could help to better understand the filamentous proliferation of these bacteria as well as to improve their application in the field of bioremediation.

The identification of filamentous bacteria is often based only on their filamentous morphotype and can lead to ambiguous species assignment (Eikelboom 1975; Martins et al. 2004). Furthermore, some of the filamentous bacteria can also grow as single cells depending on the environmental conditions and cannot be identified by their morphotype as filaments do (Rossetti et al. 1997; Jenkins et al. 2004). In fact, little is known about the factors that govern the induction of filamentous proliferation from such single cells. Moreover, the hypothesis of filament formation by fast chaining of single cells remains to be demonstrated. Elucidating the factors that may favour filamentous over single-cell growth of such bacterial species thus requires to quantify both morphotypes separately and to determine the proportion of single cells versus filaments under varying conditions. However, filamentous bacteria including those involved in bulking episodes and presenting this dual morphotype are not easily grown as axenic cultures (Tomei et al. 1998; Blackall et al. 2000). Hence, the fundamental understanding of the factors inducing filamentous growth from single cells under laboratory conditions is still poorly documented.

Sphaerotilus natans is chosen here as a model of filamentous sheath-forming bacteria to investigate the triggering factors governing filamentous growth from single cells since it is able to grow either as single cells -measuring around $1-2 \mu \mathrm{m}$ in diameter and $1-10 \mu \mathrm{m}$ in length (Spring 2006, Gridneva et al. 2011)- or as ensheathed cells forming filaments, and it can be easily cultivated under laboratory conditions. $\underline{\text { S. natans }}$ sheath is a polymer (termed thiopeptidoglycan) which consists in a pentasaccharide repeating unit (Kondo et 
mechanisms can be very different depending on the microorganism (Claessen et al. 2014). S. natans filamentous growth consists in the alignment and cell division of single cells inside the sheath (Takeda et al. 2012). In contrast, for other well-known microorganisms (e.g. Escherichia coli, Visvalingam et al. 2012 or Bacillus cereus, den Besten et al. 2009), the filamentation is the result of cell division inhibition due to stress conditions (Bouché and Pichoff, 1998). The potential of S. natans as scavenger for inorganic pollutants has been recently reviewed (Seder-Colomina et al., 2014). In addition, S. natans has been occasionally identified in nutrient-rich industrial wastewaters (Van Veen et al. 1978; Pellegrin et al. 1999; Contreras et al. 2000). Therefore, few studies have yet been dedicated to the factors affecting S. natans sheath formation and filamentous growth. For instance, it has been demonstrated that at high concentrations of peptone $(>0.2 \%)$ the filamentation pathway is perturbed (Gaudy and Wolfe 1961). In addition, it has been shown that $\mathrm{Ca}^{2+}$ concentrations higher than $0.1 \mathrm{mM}$ induce the formation of sheaths and therefore filamentous proliferation (Dias et al. 1968a). The effect of substrate concentration has also been tested and low nutrient-content plates (0.1\% NB agar) result in $S$. natans filamentous growth while rich medium (1\% NB) leads to single-cell development (Suzuki et al. 2002). Oxygen influence on S. natans filamentation has been suggested after observation of bulking in WWTP (Strom and Jenkins 1984; Richard et al. 1985) and in lab-scale activated sludge units (Palm and Parker 1980, Tanaka et al. 1985), as well as in pure and mixed culture experiments (Dias et al. 1968b). However, uncertainties remain on the relative proportions of filaments versus single cells in these and other studies when quantifying filamentous bacteria. The suitability of the procedures used to separate and quantify the two morphotypes in pure or mixed cultures had not been investigated in detail (Gaudy and Wolfe 1961; Dias et al. 1968b; Gino et al. 2010). Furthermore, analysis of microscopy images may be unable to distinguish ensheathed cells inside the filaments from single cells or single cells from different bacterial species (Gaval and Pernelle 2003; Contreras et al. 2004; Jassby et al. 2014). Combining separation techniques with modern strain-specific techniques for bacterial counting may thus help to overcome these difficulties.

In the present study we have evaluated the effect of a moderate oxygen depletion as a factor favouring the filamentous or single-cell growth of $S$. natans through an accurate counting of the two morphotypes in axenic cultures, using a differential filtration procedure coupled with quantitative PCR. 


\section{Materials and Methods}

\section{Bacterial strain and growth conditions}

Various strains of Sphaerotilus were found to present different responses to oxygen upon preliminary tests, as filamentation from single cells was induced at different oxygen availabilities for each strain tested (Supplementary Fig. S1). The strain presenting the broadest dependence of the morphotype on oxygen concentration was chosen for the present study. The selected strain Sphaerotilus natans ATCC 15291 was initially grown in solid CGYA media ( $0.5 \%$ casitone, $1 \%$ glycerol, $0.1 \%$ yeast extract and $1.2 \%$ agar) for $\sim 24$ hours until it reached the exponential growth phase. Bacteria were then recovered from the plates, resuspended in CGY broth (0.5\% casitone, $1 \%$ glycerol and $0.1 \%$ yeast extract) and filtered through a $3 \mu \mathrm{m}$ pore-size polycarbonate membrane filter (Isopore ${ }^{\mathrm{TM}}$, Millipore ${ }^{\circledR}$ ) in order to obtain an inoculum for the batch cultures that mostly contained single cells.

Batch experiments were designed to study the role of dissolved oxygen (DO) concentration in influencing S. natans filamentation and sheath-formation from single cells. Two types of batch culture conditions were used in triplicate experiments in order to measure the proportion of filaments versus single cells, under oxygen saturated conditions or under depleted oxygen conditions. The first condition, referred to as 'actively aerated', corresponds to oxygen-saturated conditions obtained by continuously aerating the growth medium in glass bottles with an active air bubbling system. The second condition referred to as 'passively aerated', lead to progressive deoxygenation of the medium upon cell respiration and was obtained by passively aerating the medium by air diffusion through a cotton plug. For both culture conditions, $250 \mathrm{ml}$ CGY broth $(0.5 \%$ casitone, $1 \%$ glycerol and $0.1 \%$ yeast extract) were inoculated at an absorbance of 0.03 (at $600 \mathrm{~nm}$ ) using the previously $3 \mu \mathrm{m}$-filtered inoculum of $S$. natans. Bottles were agitated at $100 \mathrm{rpm}$ for 48 hours of incubation. The temperature of $30.0{ }^{\circ} \mathrm{C}$ and $\mathrm{pH} 7 \underline{0}$ were kept constant and were measured using a SevenGo ${ }^{\mathrm{TM}}$ SG2 (Mettler Toledo). In both cases a YSI Model 57 Dissolved Oxygen Meter (YSI Incorporated) was also used to monitor oxygen as a function of time. Optical density was measured throughout the 48 hours of incubation, but it was found to be inaccurate when quantifying filamentous biomass (Supplementary Fig. S2).

\section{Confocal Laser Scanning Microscopy (CLSM)}



polymeric substances (EPS) and sheath formation, samples were double-stained with the non-specific bacteria dye Syto ${ }^{\circledR} 61$ Red Fluorescent Nucleic Acid Stain (LifeTechnologies ${ }^{\mathrm{TM}}$ ) targeting DNA and with two different lectins coupled with green fluorescent FITC. These Pisum sativum agglutinin (PSA) and Wheat germ agglutinin (WGA) lectins (Sigma-Aldrich ${ }^{\circledR}$ ) bind sugar residues from the EPS (terminal $\alpha$-D-mannosyl-like) and sheath (proteins containing $\beta(1 \rightarrow 4)-\mathrm{N}$-acetyl-D-glucosamine-like residues), respectively. Samples were incubated for 15 minutes with Syto ${ }^{\circledR} 61$, PSA and WGA and then washed to remove the unbound Syto ${ }^{\circledR} 61$ and lectins. In parallel, Fluorescence in situ hybridization (FISH) was used to verify S. natans purity in the process of the culture. The specific 16S rRNA-targeting probe SNA - 5 '-labeled with Cy3- used in this study (Wagner et al. 1994) was purchased at Eurofins MWG Operon (Ebersberg, Germany). Samples were prepared according to a 3-step protocol (Amann et al. 1990; Manz et al. 1992): 1) cells were dehydrated with ethanol to permeabilize the cell membrane to SNA probe; 2) they were then incubated with the probe for 90 minutes at $46^{\circ} \mathrm{C}$ to hybridize the probe and the targeted $16 \mathrm{~S}$ rRNA; 3) cells were finally washed to remove the unbound probe. All samples were observed under a CLSM Zeiss Axiovert 200M LSM 510 META.

\section{Filtration procedure coupled to DNA extraction}

A specific filtration procedure was developed in the present study in order to quantify separately the total biomass, the filaments and the single cells, in axenic cultures of S. natans containing both morphotypes (Supplementary Fig. S3). This filtration procedure provides three different samples: the total biomass (referred to as 'global culture'), the fraction of bacteria retained on a $3 \mu \mathrm{m}$ pore-size filter (referred to as 'filaments') and those who passed through the $3 \mu \mathrm{m}$ pore-size filter (referred to as 'single cells'). To avoid filter clogging in exponential and stationary growth phases, different dilutions of the culture were performed in the experiment prior to the filtration step to a final volume of $5 \mathrm{ml}$. An aliquot of $1.35 \mathrm{ml}$ of the diluted sample was then transferred to a $2 \mathrm{ml}$ tube containing $135 \mu$ of SDS $25 \%$ and $0.4 \mathrm{~g}$ of zirconium beads to disrupt cells to extract DNA (bead-beating tubes). The remaining $3.65 \mathrm{ml}$ were filtered through a $3 \mu \mathrm{m}$ poresize polycarbonate membrane filter (Isopore ${ }^{\mathrm{TM}}$, Millipore ${ }^{\circledR}$ ). The filtration membrane was then recovered and placed in a bead-beating tube with $1.35 \mathrm{ml}$ fresh CGY medium; $1.35 \mathrm{ml}$ of the $3 \mu \mathrm{m}$-filtered culture were also 
for Vortex-Genie ${ }^{\circledR}$ at maximum speed. Phenol-chloroform-isoamyl (PCI) was added to samples (vol:vol 1:1) and centrifuged in Phase-Lock Gel ${ }^{\mathrm{TM}}$ tubes (5PRIME), to ensure DNA quality extraction by removing proteins and PCI residues. The DNA was recovered after precipitation in 2-propanol (vol:vol 1:1) at $-20^{\circ} \mathrm{C}$ overnight. Sampling, filtration and DNA extraction were done in triplicate for each sampling time.

\section{Scanning Electron Microscopy (SEM)}

SEM was used to validate the efficiency of the above filtration step at various times and dilutions. Two types of samples were observed: 1) samples filtered using $3 \mu \mathrm{m}$ filters and 2) samples double-filtered, first at $3 \mu \mathrm{m}$ and subsequently at $0.22 \mu \mathrm{m}$. Filters were deposited on carbon tape and coated with a thin carbon film. SEM observations were performed with a Field Emission Gun Scanning Electron Microscope (GEMINI ZEISS Ultra55) operating at 2 to $5 \mathrm{kV}$.

\section{Quantitative real-time PCR (qPCR)}

At successive sampling times throughout the batch cultures, DNA was extracted from the three samples separated by our filtration procedure, i.e. global culture, filaments, and single cells. The integrity and quality of extracted DNA were systematically checked on $1 \%$ agarose gel electrophoresis (data not shown) prior to the quantification by qPCR analysis. For this purpose we used primers targeting the sthA gene of $S$. natans, which is involved in both sheath and EPS synthesis (Suzuki et al. 2002). The choice of sthA gene and the design of sthA primers are detailed in the Supplementary Fig. S $3 \underline{4}$.

Samples were analyzed using Multiplate ${ }^{\circledR}$ PCR Plates ${ }^{\mathrm{TM}}$ Low-Profile 96-well plates (Bio Rad) in a CFX 96 ${ }^{\mathrm{TM}}$ Real-Time PCR Detection System (Bio Rad). The qPCR reaction mixture (23 $\mu$ l) was added to global culture, filaments and single cells extracted DNA $(2 \mu \mathrm{l})$ to give the following final concentrations of components: sthA RP and sthA FP $300 \mathrm{nM}$ and $\mathrm{iQ}^{\mathrm{TM}} \mathrm{SYBR}^{\circledR}$ Green Supermix (Bio Rad) Q.S. to 1U of iTaq DNA polymerase. qPCR was performed with the following cycling program: 3 min at $95^{\circ} \mathrm{C} ; 40$ cycles consisting of $15 \mathrm{sec}$ at $95^{\circ} \mathrm{C}, 30 \mathrm{sec}$ at $60^{\circ} \mathrm{C}$, and $30 \mathrm{sec}$ at $72^{\circ} \mathrm{C}$ followed by a melt curve from $60^{\circ} \mathrm{C}$ to $95^{\circ} \mathrm{C}$ (with increasing steps of $0.5^{\circ} \mathrm{C}$ ) at intervals of $10 \mathrm{sec}$. NTC controls $(2 \mu \mathrm{l}$ of molecular biology grade DNAfree water) were also run. Tests were conducted in triplicate.

The standard curves for each assay were generated by the amplification of serial 10 -fold dilutions of a linearized plasmid pEX-A containing a sequence of 243 bp encompassing the amplicon. The original plasmid 
was synthesized by Eurofins MWG Operon (Ebersberg, Germany). It was then linearized with the restriction enzyme HindIII in order to perform an accurate quantitative PCR (Hou et al. 2010). Its concentration was fixed at $33 \mathrm{ng}^{-1} \mathrm{l}^{-1}\left(1.12 \times 10^{10}\right.$ copies $\left.\mu \mathrm{l}^{-1}\right)$. This value was determined using the Biowave II spectrophotometer (Biochrom). After that, the 10 -fold dilution series from $10^{8}$ to $10^{2}$ copies sthA $\mu l^{-1}$ was prepared in molecular biology grade DNA-free water. The quantification limit is defined as the lowest concentration of standard in the linear range that differed at least from 1 log unit (equivalent to 3.3 threshold cycles) from the NTC (Smith et al. 2006); in this case, $10^{2}$ copies of sthA per qPCR reaction. Each standard was tested in triplicate.

Data analysis was carried out with CFX Manager ${ }^{\mathrm{TM}}$ V1.0 software (Bio-Rad). The level of contamination -given by negative controls and NTC- and the qPCR efficiency were checked for each assay. The qPCR efficiency (E) was calculated from standard curves using the following formula

$$
\left.E=\left(-1+10^{/-1 / \text { slope }}\right) \times 100 \text { (eq. } 1\right)
$$

where the slope was obtained by the regression analysis between the threshold cycles (Ct) and the logarithm number of sthA copies. The qPCR efficiency of all plates run was between $90 \%$ and $98 \%$ with a regression coefficient value $\left(\mathrm{R}^{2}\right)$ systematically above 0.98 . Results were validated only when NTC controls were detected after $33 \mathrm{Ct}$. qPCR results were converted to sthA copies $\mathrm{ml}^{-1}$ culture depending on the dilution factors applied during the sampling process. Arithmetic means and standard deviation were calculated from qPCR and sample triplicates.

\section{Results}

\section{Evolution of pH and oxygen availability in batch cultures}

Under actively aerated conditions, the medium was saturated in oxygen with $\left[\mathrm{O}_{2}\right]_{\mathrm{aq}}=7.6 \pm 0.1 \mathrm{mg} \mathrm{l}^{-1}$ throughout the 48 hours of incubation. In contrast, in the passively aerated culture, the DO concentration decreased from $6.4 \mathrm{mg} \mathrm{l}^{-1}$ to values below $4 \mathrm{mg} \mathrm{l}^{-1}$ after 4 hours of incubation due to bacterial activity, and remained at $2.9 \pm 0.4 \mathrm{mg} \mathrm{l}^{-1}$ after 8 hours (Fig. $\underline{1} z$ ). Under both batch culture conditions, $\mathrm{pH}$ remained constant throughout the experiments, at $7.1 \pm 0.1$, indicating that potential changes in filamentation could not be attributed to a pH-related stress but rather to the significant difference in DO.

\section{Qualitative evaluation of the dual morphotype in batch cultures}


Depending on the culture conditions, CLSM analyses displayed different contrasted fluorescence for $S$. natans morphotypes, sheath and EPS (Fig. 233), which suggested that oxygen availability influenced singlecell vs. filamentous growth, EPS synthesis and sheath formation by S. natans. The inoculum (Fig. 23a) was composed mostly of single cells, which did not have any sheath or EPS and therefore did not present lectin staining. After 48 hours of incubation, in the actively aerated culture (Fig. 23b) single cells were the predominant morphotype. No sheath was observed, whereas lectins were slightly bound on the periphery and deeply at the poles of the single cells, suggesting an EPS production concentrated in these parts of the cells. Under passively aerated conditions (Fig. 233c) S. natans was present mainly as filaments and the fluorescence of the lectins revealed the sheath formation and EPS synthesis. In all cases, the use of S. natans-specific FISH (data not shown) made it possible to successfully discard any contamination problems that could have affected growth patterns.

\section{Selective filtration}

SEM images (Fig. 34) show that the inoculum contained almost exclusively single cells that passed through the $3 \mu \mathrm{m}$ pore-size filter (Fig. $\underline{3} 4 \mathrm{a}$ ), and that were further retained on the $0.22 \mu \mathrm{m}$ filter (Fig. $\underline{3} 4 \mathrm{~b}$ ). However, a few cells forming aggregates were occasionally observed on the surface of the $3 \mu \mathrm{m}$ filter (Fig. 34a, Insert). After 48 hours of incubation, the actively aerated culture was predominantly composed of single cells that passed through the $3 \mu \mathrm{m}$ filter and that were retained on the $0.22 \mu \mathrm{m}$ filter (Fig. $\underline{3} 4 \mathrm{~d}$ ). Occasionally, a few aggregates of single cells were observed after 48 hours of incubation on the $3 \mu \mathrm{m}$ filter surface (Fig. 34c, Insert). In contrast, after 48 hours of incubation, the passively aerated culture contained mostly filaments retained by the $3 \mu \mathrm{m}$ filter (Fig. $\underline{3} 4 \mathrm{e}$ ). The remaining single cells and some rare filaments were observed on the $0.22 \mu \mathrm{m}$ filter (Fig. $\underline{3} 4 \mathrm{f}$ ). No significant clogging of the filter was observed in any case. Altogether, these SEM observations validate the filtration procedure, showing that most filaments were retained on the $3 \mu \mathrm{m}$ filter, whereas the corresponding filtrate consisted almost exclusively of single cells that could be further retained by the $0.22 \mu \mathrm{m}$ filtration.

\section{Filamentous vs. single-cell growth}


Growth curves of global culture as well as filaments and single cells of $S$. natans obtained from qPCR

228

data after differential filtration are displayed in Figure $\underline{4} 5$. They demonstrate significant differences in the proportions of the two morphotypes as a function of oxygen availability in the batch cultures.

Under actively aerated conditions (Fig. 45a), a lag phase of at least 8 hours was observed. The global culture then yielded a rapid growth phase, parallel to the single cells growth curve, and reached a maximum value of $6.4 \times 10^{6}$ copies of sthA. Filaments in this case represented a low proportion of the culture. Indeed, the fractions of single cells and filaments in the culture (Fig. 54ab, Insert) remain rather constant throughout the incubation ( $83.3 \pm 5.9 \%$ and $16.7 \pm 5.9 \%$ on average, respectively). The increase in the number of copies of sthA corresponding to filaments after 24 hours of incubation could be explained by the presence of small aggregates of single cells on the filter (Fig. $\underline{3} 4 \mathrm{c}$, Insert).

In contrast, under passively aerated conditions (Fig. 45b), the global culture as well as the filaments presented a classical bacterial growth curve, with a lag phase that lasted for approximately 4 hours. The proportion of sthA copies from single cells dramatically decreased with time and became much lower than that of filaments especially after 16 hours of incubation. Indeed, in the stationary phase, i.e. after 24 hours of incubation, the proportion of single cells was $14.3 \pm 3.4 \%$ while filaments accounted for up to $85.7 \pm 3.4 \%$ of the total biomass (Fig. 4 5 b, Insert). Finally, under passively aerated conditions the maximum total number of sthA copies was $1.9 \times 10^{8}$ that is 30 times higher than under actively aerated conditions, suggesting that saturated oxygen conditions are not the most favourable conditions for S. natans growth.

\section{Discussion}

\section{Differential quantification of single cells and filaments}

The selective filtration procedure coupled to DNA extraction and amplification, as developed in the present study, is shown to be an effective and accurate method to evaluate factors favouring the filamentous growth of S. natans. This differential quantification methodology is faster than imaging methods and overcomes most of their limitations. For instance, manual counting under the microscope and the sludge volume index (SVI) have been used to highlight correlations between both total filament length and total 
number of filaments per mg TSS (Palm and Parker 1980). In the same way, a filament index (FI) varying from 0 (no filament) to 5 (sludge population extremely dominated by filaments) has been often used for characterizing activated sludge, but it is rather qualitative and influenced by the subjectivity of the experimenter (Eikelboom and Van Buijsen 1981).

More recently, image processing methods have been focused on the quantification of filamentous bacteria. FISH imaging was used for filament counting but this method was found to be time consuming since a tenfold manual counting on a whole microscope slide was necessary to obtain reliable data for each sample (Gaval and Pernelle 2003). Automatic image analyses to quantify filamentous bacteria from activated sludge have significantly improved the method (Contreras et al. 2004; Jassby et al. 2014). In these latter studies, phase contrast microscopy was used and 9 to 15 microscope field images were processed using Global Lab Image 2.10 (Data Translation, Inc.) or ImageJ V1.37 (National Institutes of Health) image analyses software. Filament quantification was related to the number of pixels corresponding to filaments using a correction factor. While Gaval and Pernelle (2003) and Jassby et al. (2014) did not take into account the single-cell microorganisms present in the samples, Contreras et al. (2004) developed a model to discern a single-cell small cocci (strain E932) from S. natans ensheathed cells found inside the filaments. Unfortunately, this method by itself could not be applied to quantify separately both morphotypes of $S$. natans, as the single cells have the exact same shape as the ensheathed ones forming the filaments. were separated by a suitable filtration procedure. The optimal size of the generated amplicons recommended by qPCR commercial kits (e.g. SYBR ${ }^{\circledR}$ Green or Taqman ${ }^{\circledR}$ ) is between 50 and 150 bp as too long amplicons may lead to poor amplification efficiency. The amplification products of the sthA primers developed here have a length of $143 \mathrm{bp}$, which is optimal for qPCR results. The qPCR reaction values obtained for the average slope, E, $\mathrm{R}^{2}$ and NTC controls also assure the effectiveness of the amplification reaction and therefore the accuracy of the quantification.

The present results clearly demonstrate that dissolved oxygen concentration plays a crucial role in $S$. 

growth from the inoculum of single cells. Few studies have similarly reported that low oxygen concentrations could induce the proliferation of S. natans filaments. For instance, Palm and Parker (1980) reported S. natans bulking due to its filamentous proliferation (measured as SVI), in laboratory activated sludge at DO concentrations $\leq 5.5 \mathrm{mg} \mathrm{l}^{-1}$. In the same way, Gino et al. (2010) found that $S$. natans grew predominantly as filaments forming biofilms in a groundwater well with DO values of $6.4-3.6 \mathrm{mg} \mathrm{l}^{-1}$. Dias et al. (1968b) reported filamentous growth of $S$. natans at DO concentrations of $6.9-7.8 \mathrm{mg} \mathrm{l}^{-1}$ ( oxygen saturated conditions), which seems in contradiction with our and previously mentioned studies. However, Dias et al. results were based on the measurements of dry weight of total biomass, which cannot discriminate between single cells and filaments. In addition, oxygen was not supplied during the first 24 hours of batch culture in their experiments. As shown in the present study, after 24 hours of incubation without any active supply of air the dissolved oxygen concentration is depleted due to bacterial activity, and hence the filamentation of $S$. natans is induced.

In addition, here we showed that oxygen affected not only the growth morphotype but also the quantity of total cells. Indeed, saturated oxygen conditions negatively impacted total bacterial growth (30 times less growth in the actively aerated culture). This fact suggests that elevated DO stresses $S$. natans. Hence, singlecell growth would be a response to stress and filaments would be the predominant morphotype under favourable culture conditions. This hypothesis is supported by a recent publication (Park et al. 2014) in which S. natans changed from filaments to single cells in response to the stress produced by full anoxic culture conditions.

The method developed here makes it possible to accurately quantify S. natans under its two growth morphotypes, which may help in identifying other factors favouring filamentous growth for this and other microorganisms of socio-economical and ecological interest. Furthermore, future investigations of a hypothetical reversibility of the filamentous growth may also help to better understand the mechanisms of its recurrent filamentous proliferation. 
The authors would like to thank the European Commission for providing financial support through the Erasmus Mundus Joint Doctorate Programme $\mathrm{ETeCoS}^{3}$ (Environmental Technologies for Contaminated Solids, Soils and Sediments) under the grant agreement FPA n²010-0009. In addition, the authors would like to thank Dr. Karim Benzerara for fruitful discussion and Imène Esteve for her help with Scanning Electron Microscope analyses.

The purchase of the Scanning Electron Microscope (SEM) facility of the Institut de Minéralogie, de Physique des Matériaux et de Cosmochimie (IMPMC) was supported by Région Ile-de-France grant

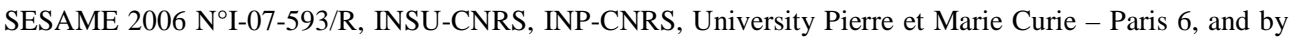
the French National Research Agency (ANR) grant no. ANR-07-BLAN-0124-01.

The Confocal Laser Scanning Microscope (CLSM) Zeiss Axiovert 200M LSM 510 META and the CFX 96 ${ }^{\mathrm{TM}}$ Real-Time PCR Detection System (Bio Rad) used in this work are part of the MIMOSE experimental platform, were funded by the Région Ile-de-France.

\section{Bibliography}

Amann R, Binder B, Olson R, Chisholm S, Devereux R, Stahl D. (1990) Combination of 16S rRNAtargeted oligonucleotide probes with flow cytometry for analyzing mixed microbial populations. Appl Environ Microbiol. 56: 1919-1925.

Blackall LL, Seviour EM, Bradford D, Rossetti S, Tandoi V, Seviour RJ. (2000) “Candidatus Nostocoida limicola”, a filamentous bacterium from activated sludge. Int J Syst Evol Microbiol. 50: 703-709.

Bouché J-P, Pichoff S (1998) On the birth and fate of bacterial division sites. Mol Microbiol. 29: 19-26. Claessen D, Rozen DE, Kuipers OP, Søgaard-Andersen L, van Wezel GP (2014) Bacterial solutions to multicellularity: a tale of biofilms, filaments and fruiting bodies. Nature Reviews Microbiol. 12: 115-124.

Contreras EM, Giannuzzi L, Zaritzky NE. (2000) Growth kinetics of the microorganism Sphaerotilus natans in a model system of a food industry wastewater. Water Res. 34: 4455-4463. 

between filamentous and non-filamentous bacteria. Water Res. 38: 2621-2630.

Den Besten HMW, Mols M, Moezelaar R, Zwietering MH, Abee T (2009) Phenotypic and transcriptomic analyses of mildly and severely salt-stressed Bacillus cereus ATCC 14579 cells. Appl Environ Microbiol. 75: 4111-4119.

Dias FF, Dondero NC, Finstein MS. (1968b) Attached growth of Sphaerotilus and mixed populations in a continuous-flow apparatus. Appl Microbiol. 16: 1191-1199.

Dias FF, Okrend H, Dondero NC. (1968a) Calcium nutrition of Sphaerotilus growing in a continuos-flow apparatus. Appl Environ Microbiol. 16: 1364-1369.

Eikelboom D, Van Buijsen H. (1981) Microscopic sludge investigation manual. TNO - Research Institute for Environmental Hygiene. TNO Report A 94a.

Eikelboom, DH. (1975) Filamentous organisms observed in activated sludge. Water Res. 9: 365-388.

Gaudy E, Wolfe RS. (1961) Factors affecting filamentous growth of Sphaerotilus natans. Appl Microbiol. 9: $580-584$.

Gaval G, Pernelle J-J. (2003) Impact of the repetition of oxygen deficiencies on the filamentous bacteria proliferation in activated sludge. Water Res. 37: 1991-2000.

Gino E, Starosvetsky J, Kurzbaum E, Armon R. (2010) Combined chemical-biological treatment for prevention/rehabilitation of clogged wells by an iron-oxidizing bacterium. Environ Sci Technol. 44: 31233129. Taxonomic investigation of representatives of the genus Sphaerotilus: descriptions of Sphaerotilus montanus sp. nov., Sphaerotilus hippei sp. nov., Sphaerotilus natans subsp. natans subsp. nov. and Sphaerotilus natans subsp. sulfidivorans subsp. nov., and an emended description of the genus Sphaerotilus. Int J Syst Evol Microbiol. 61:916-925.

Hou Y, Zhang H, Miranda L, Lin S. (2010) Serious overestimation in quantitative PCR by circular (supercoiled) plasmid standard: microalgal pcna as the model gene. PLoS One 5: e9545. 
Jassby D, Xiao Y, Schuler AJ. (2014) Biomass density and filament length synergistically affect activated sludge settling: systematic quantification and modeling. Water Res. 48: 457-465.

Jenkins D. (1992) Towards a comprehensive model of activated sludge bulking and foaming. Water Sci Technol. 25: 215-230.

Jenkins D, Richard M, Daigger G. (2004) Manual of the causes and control of activated sludge bulking, foaming, and other solids separation problems. 3rd Edition. Lewis Publishers.

Kondo K, Takeda M, Ejimaa W, Kawasaki Y, Umezua T, Yamada M, Koizumi J, Mashima T, Katahirab M. (2011) Study of a novel glycoconjugate, thiopeptidoglycan, and a novel polysaccharide lyase, thiopeptidoglycan lyase. Inter J Biol Macromol. 48:256-262.

Lodi A, Solisio C, Converti A, Del Borghi M. (1998) Cadmium, zinc, copper, silver and chromium (III) removal from wastewaters by Sphaerotilus natans. Bioprocess Eng. 19: 197-203.

Manz W, Amann R, Ludwig W, Wagner M, Schleifer K. (1992) Phylogenetic oligodeoxynucleotide probes for the major subclasses of proteobacteria: Problems and solutions. Syst Appl Microbiol. 15: 593-600.

Martins AMP, Pagilla K, Heijnen JJ, van Loosdrecht MCM. (2004) Filamentous bulking sludge - a critical review. Water Res. 38: 793-817.

Pagnanelli F, Esposito A, Toro L, Vegliò F. (2003) Metal speciation and pH effect on $\mathrm{Pb}, \mathrm{Cu}, \mathrm{Zn}$ and $\mathrm{Cd}$ biosorption onto Sphaerotilus natans: Langmuir-type empirical model. Water Res. 37: 627-633.

Palm J, Parker D. (1980) Relationship between organic loading, dissolved oxygen concentration and sludge settleability in the completely-mixed activated sludge process. J Water Pollut Control Fed. 52: 24842506.

Park S, Kim D-H, Lee J-H, Hur H-G. (2014) Sphaerotilus natans encrusted with nanoball-shaped Fe(III) oxide minerals formed by nitrate-reducing mixotrophic Fe(II) oxidation. FEMS Microbiol Ecol. doi: $10.1111 / 1574-6941.12372$

Patziger M, Kainz H, Hunze M, Józsa J. (2012) Influence of secondary settling tank performance on suspended solids mass balance in activated sludge systems. Water Res. 46: 2415-2424.

Pellegrin V, Juretschko S, Wagner M, Cottenceau G. (1999) Morphological and biochemical properties of a Sphaerotilus sp. isolated from paper mill slimes. Appl Environ Microbiol. 65: 156-162. 
Richard M, Hao O, Jenkins D. (1985) Growth kinetics of Sphaerotilus species and their significance in

384 activated sludge bulking. J Water Pollut Control Fed. 57: 68-81.

Rossetti S, Hildisch D, Christensson C, Del Dot T, Blackall LL, Tandoi V. (1997) Isolation and identification of an Eikelboom Type 1863 strain as Acinetobacter johnsonii. Water Res. 31: 657-660.

Seder-Colomina M, Morin G, Benzerara K, Ona-Nguema G, Pernelle J-J, Esposito G, van Hullebusch ED. (2014) Sphaerotilus natans, a neutrophilic iron-related sheath-forming bacterium: perspectives for metal remediation strategies. Geomicrobiol J. 31: 64-75.

Silverstein J, Mines R, Sherrard J, Weber A, Aitken M. (1990) Activated sludge. Res J Water Pollut Control Fed. 62: 398-406.

Smith CJ, Nedwell DB, Dong LF, Osborn AM. (2006) Evaluation of quantitative polymerase chain reaction-based approaches for determining gene copy and gene transcript numbers in environmental samples. Environ Microbiol. 8: 804-815.

Spring S. (2006) The genera Leptothrix and Sphaerotilus. In: Dworkin M, Falkow S, Rosenberg E, Schleifer K-H, Stackebrandt E, Editors. The Prokaryotes, vol 5. New York: Springer. p758-777.

Strom PF, Jenkins D. (1984) Identification and significance of filamentous microorganisms in activated sludge. J Water Pollut Control Fed. 56: 449-459.

Suzuki T, Kanagawa T, Kamagata Y. (2002) Identification of a gene essential for sheathed structure formation in Sphaerotilus natans, a filamentous sheathed bacterium. Appl Environ Microbiol. 68: 365-371.

Takeda M, Miyanoiri Y, Nogami T, Oda K, Saito T, Kato K, Koizumi J, Katahira M. (2007) Structural analysis of the fundamental polymer of the sheath constructed by Sphaerotilus natans. Biosci Biotechnol Biochem. 71: 2992-2998.

Tanaka H, Kurano N, Ueda S, Ueda S, Okazaki M, Miura Y. (1985) Model system of bulking and flocculation in mixed culture of Sphaerotilus sp. and Pseudomonas sp. for dissolved oxygen deficiency and high loading. Water Res. 19: 563-571.

Tomei MC, Levantesi C, Rossetti S, Tandoi V. (1999) Microbiological characterisation of pure cultures and its relevance to modelling and control of bulking phenomena. Water Sci Technol. 39: 21-29 

Microbiol Rev. 42: 329-356.

\section{List of Figures and Captions}

Fig. 1 Filtration method developed for differential amplification by qPCR based on growth morphotypes

Fig. $\underline{12}$ Oxygen and $\mathrm{pH}$ measurements of actively and passively aerated cultures of Sphaerotilus natans throughout the 48 hours of incubation: $(\ominus \underline{\boldsymbol{\Delta}}) \mathrm{pH}$ and $(\boldsymbol{\bullet})$ oxygen of actively aerated culture, $(\square \underline{\boldsymbol{\nabla}}) \mathrm{pH}$ and

) oxygen of passively aerated culture

Fig. 23 CLSM imaging of (red) Syto61 ${ }^{\circledR}$ and (green) PSA and WGA lectins coupled to FITC for (a) initial inoculum of Sphaerotilus natans, (b) actively aerated culture after 48 hours of incubation, and (c) passively aerated culture after 48 hours of incubation. Scale bars represent $10 \mu \mathrm{m}$

Fig. 34 SEM observations of the $3 \mu \mathrm{m}$ pore-size filters (a, c and e) and $0.22 \mu \mathrm{m}$ pore-size filters (b, d and f): (a, b) initial inoculum of Sphaerotilus natans, (c, d) actively aerated culture after 48 hours of incubation, and (e, f) passively aerated culture after 48 hours of incubation. Scale bars represent $5 \mu \mathrm{m}$

Fig. 45 Sphaerotilus natans differential-growth curves,

, (ム) global culture, single cells and filaments, under (a) actively aerated and (b) passively aerated culture conditions. Inserted figures display the 